\title{
Antimicrobial Activity of Nanopharmaceutical on Klebsiella Pneumoniae Strains
}

\author{
Inglid Silva ${ }^{1}$, Thaís Veriato ${ }^{1}$, Rafaela Silva ${ }^{1}$, Marcela Cândido², Leandro Raniero ${ }^{2}$, Maiara Castilho ${ }^{1}$ \\ ${ }^{1}$ Universidade de Vale do Paraíba/Instituto de Pesquisa e Desenvolvimento, Laboratório de Bionanotecnologia, Avenida \\ Shishima Hifumi, 2911, Urbanova - 12244-000, São José dos Campos, Brasil \\ inglidfontoura@hotmail.com, thaissveriato@gmail.com, rafaelamsilva13@hotmail.com, mcastilho@univap.br \\ ${ }^{2}$ Universidade de Vale do Paraíba/Instituto de Pesquisa e Desenvolvimento, Laboratório de Nanossensores, Avenida \\ Shishima Hifumi, 2911, Urbanova - 12244-000, São José dos Campos, Brasil \\ marcela.aparecida.candido@gmail.com, 1raniero@univap.br
}

\section{Extended Abstract}

Klebsiella pneumoniae (K. pneumoniae) is an important pathogen responsible for some hospital infections. The raising of the hypervirulent strains has become a public health issue due to increasing of morbidity, mortality and costs associated with infected patients $[1,2]$. Current treatment for this infection involves antibiotic therapy, but microorganisms are developing resistance to antimicrobials [2]. Thus, silver nanoparticles (AgNPs) may overcome these limitations due to their bactericidal properties as well as surface functionalization option, which would improve treatments of diseases caused by microorganisms [3, 4]. The aim of this work was to analyze the efficacy of AgNPs functionalized with antibiotics in a strain of $K$. pneumoniae with a resistance profile. The AgNPs were synthesized by the reduction of silver nitrate by sodium borohydride and functionalized to the modified Imipenem antibiotic via carbodiimide chemistry. The nanopharmaceutical was characterized by UV-Visible Spectroscopy and Dynamic Light Scattering. The Minimum Inhibitory Concentration was performed according to Clinical and Laboratory Standards Institute (M7-A9) standards [5]. The MIC and Minimum Bactericidal Concentration (MBC) of nanopharmaceutical against $K$. pneumoniae with a resistance profile were carried out using optical density values and visible growth occurred on the plates, respectively. The experiments were performed by microdilution method using different concentrations of nanopharmaceutical in a 96-well plate, incubated for $24 \mathrm{~h}$ at $35^{\circ} \mathrm{C}$ and the drop technique was used for MBC. The Surface Plasmon Resonance band for colloidal nanopharmaceutical has shown an absorption at $266 \mathrm{~nm}$ and $394 \mathrm{~nm}$, corresponding of antibiotic imipenem and the bare AgNPs, respectively, which are in agreement to an increasing of hydrodynamic diameter for $\sim 36 \mathrm{~nm}$ after functionalization procedure. The MIC and MBC analysis showed the bacteriostatic and bactericidal actions of the nanopharmaceutical, showing good results as the lowest concentration was capable of inhibiting bacterial growth. The nanopharmaceutical application has shown great bacterial inhibition power against to $K$. pneumoniae, suggesting a promising treatment for infection of strain with a resistance profile.

\section{References}

[1] S. Navon-Venezia, "Klebsiella pneumoniae: a major worldwide source and shuttle for antibiotic resistance". FEMS Microbiology Reviews, v. 41, pp. 252-275, 2017.

[2] E.M. Eichenberger, "Epidemiology and Mechanisms of Resistance of Extensively Drug Resistant Gram-Negative Bacteria", Antibiotics, vol. 8, n. 37, 2019.

[3] G. Franci, "Silver Nanoparticles as Potential Antibacterial Agents" Molecules, v. 20, p. 8856-8874, 2015.

[4] LI, W.R., "Antibacterial effect of silver nanoparticles on Staphylococcus aureus", Biometals, v. 24, p. 135-141, 2011.

[5]CLSI. "Methods for Dilution Antimicrobial Susceptibility Tests for Bacteria That Grow Aerobically; Approved StandardNinth Edition". CLSI document M07-A9. Wayne, PA: Clinical and Laboratory Standards Institute; 2012. 